DOI: $10.14451 / 2.159 .29$

\title{
НОВЫЕ ФИНАНСОВО-ПРАВОВЫЕ ИНСТРУМЕНТЫ РЕГУЛИРОВАНИЯ ЭКОНОМИЧЕСКОЙ ДЕЯТЕЛЬНОСТИ В УСЛОВИЯХ ЦИФРОВИЗАЦИИ
}

\author{
(c) 2021 Рассыльников Игорь Александрович \\ кандидат юридических наук, доцент, доцент кафедры прикладного права \\ РТУ МИРЭА, Россия, Москва
}

\begin{abstract}
Предметом настоящей статьи выступает исследование новых финансово-правовых инструментов регулирования экономической деятельности в условиях цифровизации. Цифровизация экономики предполагает трансформацию экономических отношений в условиях появления новых технологий, влияющих на взаимодействие участников финансовых отношений. Тема статьи отражает тенденции развития финансово-правового регулирования. Целью настоящей статьи является анализ трансформации механизмов финансово-правового регулирования в условиях цифровизации российской экономики. Методологию данной работы составили сравнительный, формальноюридический, аналитический методы. Результаты работы - это определение роли и содержания новых финансово-правовых инструментов регулирования экономических отношений в условиях цифровизации. Область применения результатов работы включает в себя государственную политику в области стратегического развития и управления.
\end{abstract}

Ключевые слова: публично-правовое регулирование, финансовое право, бюджет, налоги, государственные закупки, цифровая экономика

Цифровизация экономики предполагает трансформацию экономических отношений в условиях появления новых технологий, влияющих на взаимодействие субъектов финансовой деятельности и участников финансовых отношений. Развитие цифровой экономики закреплено в качестве одного из приоритетов развития российского государства в документах стратегического планирования. В частности, в указах Президента Российской Федерации от 7 мая 2018 г № 204 «О национальных целях и стратегических задачах развития Российской Федерации на период до 2024 года» [1] и от 21.07.2020 г. № 474 «О национальных целях развития Российской Федерации на период до 2030 года» [2] цифровая трансформация и поддержка малого и среднего предпринимательства названы в числе приоритетных целей.

С целью решения задачи по обеспечению ускоренного внедрения цифровых технологий в экономике и социальной сфере, Правительством Российской Федерации сформирована национальная программа «Цифровая экономика Российской Федерации», в состав которой входят следующие федеральные проекты: «Нормативное регулирование цифровой среды»; «Кадры для цифровой экономики»; «Информационная инфраструктура»; «Информационная безопасность»; «Цифровые технологии»; «Цифровое государственное управление»; «Искусственный интеллект» [3].

Трансформация экономики неизбежно влечет за собой и трансформацию финансов и финансовой системы. Это, в свою очередь, не может не отразиться на финансово-правовом регулировании, которое должно адекватно отражать изменяющиеся экономические процессы в обществе. Новые финансово-правовые инструменты в данной области ориентированы на выявление, закрепление и защиту интересов субъектов финансовых правоотношениях в условиях изменяющегося характера экономики. Это достигается через решение нескольких задач: реализацию принципа прозрачности и гласности в финансовой сфере; упрощение взаимодействия граждан с государством в финансовой сфере; оптимизацию финансового контроля.

Реализация принципа прозрачности и гласности в финансовой сфере в условиях цифровизации наиболее последовательно прослеживается в сфере бюджетного права. Уже первая редакция Бюджетного Кодекса [4] включила статью 36 которая в то время называлась «Принцип гласности». В ходе реформы бюджетного законодательства 2007-2008 годов Федеральным законом от 26.04.2007 № 63-Ф3 [5] было изменено содержание статьи 36 и сама статья получила новое название «Принцип прозрачности (открытости)». 
В отличие от классического понимания принципа гласности, как требования обязательного опубликования нормативных актов в открытой печати, принцип прозрачности в бюджетном праве имеет более широкое содержание и требует не только обязательного опубликования утвержденных бюджетов в средствах массовой информации, но и обязательной открытости для общества проектов законов (решений) о бюджете, процедур их рассмотрения и утверждения. Изменения, внесенные в Бюджетный Кодекс в 2013 году [6], расширили содержание данного принципа. Кодекс был дополнен статьей 241.2, в которой был конкретизирован порядок функционирования единого портала бюджетной системы Российской Федерации, предназначенного для обеспечения доступа к информации о бюджетной системе Российской Федерации и об организации бюджетного процесса в Российской Федерации, а также к информации об осуществлении публично-правовыми образованиями бюджетных полномочий и их участии в отношениях, регулируемых бюджетным законодательством Российской Федерации. Сам же доступ к информации, размещенной в информационно-телекоммуникационной сети «Интернет» на едином портале бюджетной системы Российской Федерации стал рассматриваться, как один из элементов принципа прозрачности в бюджетном праве.

В дальнейшем единый портал бюджетной системы был инкорпорирован в государственную интегрированную информационную систему управления общественными финансами «Электронный бюджет» (далее - система «Электронный бюджет») (http://budget.gov.ru/). В систему «Электронный бюджет» также были включены централизованные и сервисные подсистемы, предназначенные для бюджетного планирования, управления и контроля [7].

Следующий этап цифровизации бюджетной сферы затронул федеральный бюджетный процесс. Федеральный закон от 30 сентября 2017 г. N 285-Ф3 «О внесении изменений в Бюджетный кодекс Российской Федерации» [8] и Правила составления проекта федерального бюджета и проектов бюджетов государственных внебюджетных фондов Российской Федерации на очередной финансовый год и плановый период, утвержденные Постановлением Правительства РФ от 24 марта 2018 г. N 326 [9] предусмотрели, что проект федерального бюджета разрабатыва- ется в системе «Электронный бюджет». Внесение «бюджетного пакета» (проект федерального закона о федеральном бюджете и документы, прилагаемые к проекту бюджета в соответствии с ч.4 ст.192 БК РФ) в Государственную Думу начиная с 2018 года осуществляется в электронном виде.

Другим элементом принципа открытости бюджетных правоотношений, который реализуется с помощью цифровых технологий, является единая информационная система (ЕИС) в сфере государственных и муниципальных закупок (www.zakupki.gov.ru). С помощью единой информационной системы в сфере государственных и муниципальных закупок обеспечивается как возможность получать информацию о проводимых закупках, так и возможность для хозяйствующих субъектов участвовать в процедурах закупок в качестве поставщика (подрядчика, исполнителя) по государственным и муниципальным контрактам.

В соответствии со статьями 4, 7 Федерального закона от 5 апреля 2013 г. N 44-Ф3 «О контрактной системе в сфере закупок товаров, работ, услуг для обеспечения государственных и муниципальных нужд» [10] в единой информационной системы в сфере государственных и муниципальных закупок содержится, в том числе, информация об исполнении планов-графиков закупок, о реестре заключенных контрактов, а также результаты мониторинга закупок, аудита в сфере закупок, контроля в сфере закупок. Сама ЕИС в сфере государственных и муниципальных закупок поддерживает информационное взаимодействие с иными информационными ресурсами, в частности, с государственной интегрированной информационной системой управления общественными финансами «Электронный бюджет», с электронными площадками, обеспечивающими проведение определения поставщиков (подрядчиков, исполнителей) в соответствии с законодательством о контрактной системе, а также с информационной системой Федеральной антимонопольной службы, обеспечивающей ведение реестра недобросовестных поставщиков (подрядчиков, исполнителей) [11].

С использованием функционала ЕИС peaлизуется еще один финансово-правовой инструмент в сфере бюджетно-правового регулирования - общественное обсуждение закупок, предусмотренное ст.20 Федерального закона от 5 апреля 2013 г. N 44-Ф3 «О контрактной системе 
в сфере закупок товаров, работ, услуг для обеспечения государственных и муниципальных нужд» и соответствующими подзаконными актами [12]. Таким образом, законодательное оформление цифровизации бюджетных процессов служит дополнительной гарантией принципа прозрачности и одновременно с этим важным финансово-правовым инструментом финансового контроля.

Значимым финансово-правовым инструментом, опосредующим взаимодействие граждан с государством в финансовой сфере, стало законодательное закрепление сервиса «Личный кабинет налогоплательщика», первоначально запущенного на официальном сайте Федеральной налоговой службы в 2012 году. Федеральным законом от 4 ноября 2014 г. N 347-Ф3 [13] в Налоговый Кодекс введена статья 11.2, закрепляющая данный финансово-правовой инструмент и определяющая правовые последствия использования сервиса.

Личный кабинет налогоплательщика является информационным ресурсом, который размещен на официальном сайте федеральной налоговой службы в информационно-телекоммуникационной сети «Интернет». В случаях, предусмотренных Налоговым Кодексом, личный кабинет налогоплательщика может быть использован не только для передачи информации, но и для реализации налогоплательщиками и налоговыми органами своих прав и обязанностей. Так, пунктом 2 статьи $11.2 \mathrm{HK}$ предусмотрено, что личный кабинет налогоплательщика используется налогоплательщиками - физическими лицами для получения от налогового органа документов и передачи в налоговый орган документов (информации), сведений в электронной форме. Налогоплательщики могут предоставлять через личный кабинет информацию об объектах налогообложения (п.7 ст.23 НК), а налоговые органы вправе передавать налогоплательщику через личный кабинет документы, используемые своих полномочий в налоговой сфере (п. 4 ст.31 НК РФ). Пункт 4 статьи 52 НК оговаривает возможность передачи через личный кабинет налоговых уведомлений, являющихся основанием для уплаты налога, аналогичная возможность установлена для передачи требований об уплате налога (п.6 ст.69 НК). В этой связи следует согласиться с мнением Е.Г.Беликова, что цифровизация сферы налогообложения связана не только с изменением ха- рактера взаимодействия налогоплательщиков с налоговыми органами, но и с изменением налоговой правосубъектности как налогоплательщиков, так и налоговых органов [14].

Интересным технологическим инструментом, получившим свое финансово-правовое закрепление, являются онлайн-кассы. Принципиальная схема использования онлайн-касс предполагает, что хозяйствующие субъекты используют в своей деятельности кассовые аппараты, которые передают информацию о проведенных платежах через операторов фискальных данных непосредственно в налоговые органы посредством сети Интернет.

Изменения, внесенные в Федеральный закон от 22 мая 2003 г. N 54-Ф3 «О применении контрольно-кассовой техники при осуществлении расчетов в Российской Федерации» в 2016 году [15], были столь существенны, что можно было говорить о практически новом порядке применения контрольно-кассовой техники в России - изменилось все вплоть до наименования Федерального закона. Этим законом был закреплен финансово-правовой механизм использования онлайн-касс, а также сроки поэтапного перехода к применению онлайн-касс на территории Российской Федерации.

В соответствии с новой редакцией Федерального закона о применении контрольнокассовой техники на территории Российской Федерации должна применяться контрольнокассовая техника, которая обеспечивает передачу фискальных данных через сеть «Интернет» оператору фискальных данных, а также возможность направить кассовый чек на абонентский номер или адрес электронной почты покупателя (клиента) (ст.1.2 Федерального закона от 22 мая 2003 г. N 54-Ф3).

Кроме этого, после принятия Федерального закона от 3 июля 2016 г. N 290-ФЗ получил юридическое закрепление кабинет контрольнокассовой техники - информационный ресурс, который размещен на официальном сайте федеральной налоговой службы в информационнотелекоммуникационной сети «Интернет», который используется организациями, индивидуальными предпринимателями и налоговыми органами для реализации своих прав и обязанностей, установленных законодательством Российской Федерации о применении контрольнокассовой техники (ст.1.1 Федерального закона о контрольно-кассовой технике). Легко увидеть 
в данном случае аналогию с личным кабинетом налогоплательщика, о котором говорилось выше. Но вместе с тем, интересно отметить, что в отличие от сферы налогово-правового регулирования, в области применения контрольнокассовой техники использование личного кабинета для реализации прав и обязанностей является обязательным для участников соответствующих отношений.

Финансово-правовые инструменты, peгламентирующие использование контрольнокассовой техники в условиях цифровизации экономики имеют комплексный характер и призваны решить сразу несколько задач. С одной стороны, это защита финансовых интересов государства, поскольку информация о совершенной платежной операции передается через Интернет в Федеральную налоговую службу. Также это оптимизация финансового контроля, поскольку применение онлайн-касс исключает массовую проверку соблюдения Федерального закона о применении контрольно-кассовой тех- ники, и упрощает получение информации для мероприятий налогового контроля. Кроме этого, реализация норм финансового права имеет важное значение для защиты прав потребителей, поскольку даже в случае утери чека информация о проведенной операции сохраняется в системе. Кроме этого, применение онлайн-касс увязано в реализуемыми проектами в области маркировки продукции определенных видов.

В итоге отметим, что анализ отдельных финансово-правовых инструментов регулирования экономической деятельности, появившихся как отклик на процессы цифровизации экономики, показывает, что современное финансово-правовое регулирование в Российской Федерации направлено на решение комплексной задачи разграничения и защиты интересов субъектов финансовых отношений и участников экономической деятельности. Эта задача решается, прежде всего, путем регулирования порядка информационного взаимодействия между участниками.

\section{Библиографический список}

1. http://www.kremlin.ru/acts/bank/43027; дата обращения: 26.09.2021

2. http://www.kremlin.ru/acts/bank/45726; дата обращения 26.09.2021

3. паспорт программы: http://static.government.ru/media/files/urKHm0g TPPnzJlaKw3M5cNLo6gczMkPF.pdf; дата обращения: 26.08.2021

4. Собр. законодательства Рос. Федерации. 1998. N 31. Ст. 3823

5. О внесении изменений в Бюджетный кодекс Российской Федерации в части регулирования бюджетного процесса и приведении в соответствие с бюджетным законодательством Российской Федерации отдельных законодательных актов Российской Федерации: Федеральный закон от 26 апреля 2007 г. N 63-Ф3 // Собрание законодательства Российской Федерации. 2007. N 18. Ст. 2117

6. О внесении изменений в Бюджетный кодекс Российской Федерации и отдельные законодательные акты Российской Федерации в связи с совершенствованием бюджетного процесса: Федеральный закон от 7 мая 2013 г. N 104-Ф3 // Собрание законодательства Российской Федерации. 2013. N 19. Ст. 2331

7. О государственной интегрированной информационной системе управления общественными финансами «Электронный бюджет»: Постановление Правительства РФ от 30 июня 2015 г. N 658 // Собрание законодательства Российской Федерации. 2015. № 28. Ст. 4228

8. О внесении изменений в Бюджетный кодекс Российской Федерации: Федеральный закон от 30 сентября 2017 г. N 285-Ф3 // Собрание законодательства Российской Федерации. 2017. N 40. ст. 5752

9. Об утверждении Правил составления проекта федерального бюджета и проектов бюджетов государственных внебюджетных фондов Российской Федерации на очередной финансовый год и плановый период и признании утратившими силу некоторых актов Правительства Российской Федерации: Постановление Правительства РФ от 24 марта 2018 г. N 326 // Собрание законодательства Российской Федерации. 2018. N 14. Ст. 1976

10. Собрание законодательства Российской Федерации. 2013. N 14. Ст. 1652

11. О порядке функционирования единой информационной системы в сфере закупок: Постановление Правительства РФ от 23 декабря 2015 г. N 1414 // Собрание законодательства Российской Федерации. 2016. N 2 (часть I). ст. 324

12. Об утверждении Правил проведения обязательного общественного обсуждения закупок товаров, работ, услуг для обеспечения государственных и муниципальных нужд: Постановление Правительства РФ от 11 декабря 2019 г. N 1635 // Собрание законодательства Российской Федерации. 2019. N 50. Ст. 7413 
13. О внесении изменений в части первую и вторую Налогового кодекса Российской Федерации: Федеральный закон от 4 ноября 2014 г. N 347-Ф3 // Собрание законодательства Российской Федерации. 2014. N 45. Ст. 6157

14. Беликов Е.Г. Развитие финансово-правовых принципов в условиях цифровой экономики // Вестник университета им. Кутафина (МГЮА). 2020. № 9. С.40

15. О внесении изменений в Федеральный закон «О применении контрольно-кассовой техники при осуществлении наличных денежных расчетов и (или) расчетов с использованием платежных карт» и отдельные законодательные акты Российской Федерации: Федеральный закон от 3 июля 2016 г. N 290-Ф3 // Собрание законодательства Российской Федерации. 2016. N 27 (часть I). Ст. 4223 